\title{
VOCATIONAL HIGH SCHOOL TEACHERS' EFFORTS IN EQUIPPING GRADUATES WITH SOFT SKILLS BASED ON WORK DEMANDS
}

\author{
Rudi Nur Syamsudin ${ }^{1}$, Sukardi $^{2}$, and He Shiyu ${ }^{3}$ \\ ${ }^{12}$ Graduate School of Technological \& Vocational Education, Universitas Negeri Yogyakarta, Indonesia \\ ${ }^{2}$ Faculty of Education, Beijing Normal University, People's Republic of China \\ E-mail: syamsudin_rudi@yahoo.com
}

\begin{abstract}
A preliminary study in Yogyakarta showed that the graduates' enthusiasm to enter building construction study program in vocational high school was low. One of the factors affecting the graduates' enthusiasm was related to the low-level teachers' efforts in preparing the graduates' soft skills. This study aimed to identify (1) the integration level of soft skills elements, and (2) the teachers' obstacles to equipping the graduates' soft skills. It was descriptive quantitative research conducted in the study program of building construction at vocational high schools. The results of the study showed: (1) the integration level of communicative ability, integration level of cooperative competence, integration level of motivating ability, integration level of developing etiquette and moral, and integration level of building responsibility were wholly integrated. Then, the integration level of problem-solving ability and integration level of science and technology mastery was mostly integrated; (2) the obstacles included: the students' ignorance attitude, the lack of collaboration between the students' parents and the school stakeholders in developing the graduates' soft skills, the absence of soft skills training and the unsupported school culture. Those obstacles impeded the graduates' soft skills.
\end{abstract}

Keywords: integration, soft skills, teachers' efforts, vocational high school

\section{INTRODUCTION}

Vocational high school is one of the formal education institutions in Indonesia [1]. Byram \& Wenrich [2] state that vocational education is teaching people how to work effectively. Evans \& Edwin [3] also says that vocational education is part of education which makes an individual more employable in one group of occupations than in another. Vocational education is education that provides experiences, visual stimuli, affective awareness, cognitive information, or psychomotor skills, and that enhances the vocational development process of exploring, establishing, and maintaining oneself in the world off work [4]. The vocational high school aims to prepare the graduates to work [5]. Therefore, vocational high school as an educational institution which has the critical role in preparing the workers is demanded to follow the developing market needs.

As stated in the Strategic Plan of Vocational High School Training Directorate 2015 to 2019 [6], the government, especially the vocational high school training directorate, is responsible for developing the quality human recourses. It is based on the policy of the Ministry of Culture and Education which set the ratio of vocational high schools and senior high schools as 70:30. That policy aims to afford the qualified vocational high school graduates who are ready to work. In other hands, the policy aims to decrease the amount of unemployment and to increase the national economy.

Unfortunately there are some weak points in the operation of vocational high school such as only focusing on preparing the students to be a worker than an entrepreneur, responding the demand of economic development slowly, mismatching with the demand in workplace, and not giving a guarantee that the students can afford standardized work based on their study program [7]. Moreover, the literature suggests that some employers find graduates are poorly prepared for teamwork, but they recognise the excellent level of IT skills [8]. Besides, the learning process in vocational high school is dominated by the activities focusing on developing the hard skills. The portion for 
actualizing the soft skills in the learning process is still low. The lack of soft skills training causes less number of graduates accepted in the work fields. Nowadays, the requirement to be accepted in the work fields considers the soft skills quality of graduates.

A good graduate is one who has employability skills. Employability skills are a set of achievement, understanding, and personal attitudes/qualities that mark the individual as potentially more able to get the desired job and to be successful in career choice [9]. Cimatti [10] stated that the graduates have to have these soft skills: (1) problem solving; (2) analysis and synthesis of information; (3) autonomously criticism; (4) effective communication; (5) long-life learning; (6) team working; (7) initiative; (8) organization and planning. There are a lot of changes in every aspect of life in the $21^{\text {st }}$ century. The vocational high school graduates should not only be prepared with the hard skills but also the soft skills. Therefore, some industries require graduates who have hard skills and soft skills. The hard skills are the skills needed based on the work field, and the soft skills are the skills needed to support the workers' ethos in finishing their duties [11]. It is ironic that vocational high school as educational institutions which prepared the skilled graduates focuses more on the aspect of skill and knowledge or the hard skills. However, the learning ratio for the soft skills is still less. In fact, the work field prioritizes the soft skills than the hard skills. Ramlall \& Ramlall [12] state that the success at work is $85 \%$ determined by soft skills and $15 \%$ influenced by hard skills. Besides, soft skills are the characters which become the key to success and function to improve the effectiveness of working. Besides, nowadays results show that stakeholders feel that soft skills of students are not developed adequately, that there is some uncertainty about who should be responsible for developing soft skills, and that the development of soft skills is seen as a difficult task [13].
Vocational high school is an educational institution whose duties is to develop the students' knowledge and skill based on the students' competence and study program and to prepare the students' adaptation and competitiveness competence to face the work fields. Vocational education develops not only the students' hard skills but also the students' soft skills.

The worker criterion needed in this globalization era is a human resource that can balance the hard skills and soft skills. Vocational high school graduates as a worker candidate should not only have the hard skills but should also master the soft skills as the supporting aspect of the hard skills. Soft skills including teamwork, communication, and traits such as emotional intelligence are among of the attributes of greatest importance in the current labor market [14]. Truong \& Laura [15] state that soft skills refer to an array of personal skills such as the capacity to communicate, and problem-solve, possess leadership qualities, and the ability to work well in a team, be amicable, and a good listener. Santos et al. [16] state that soft skills are the skills a person has with whom they interact with their peers in both a work environment and outside. These include attitude, communicational skills, time management, critical thinking, and a host of other behaviors that are not always related to what is traditionally called intelligence. The urgency of the soft skills will be implemented usefully when the graduates enter the real life or work fields. The soft skills are categorized into communicative ability, affective ability, language ability, cooperative ability, moral and etiquette, healthy behaviour, and spiritual ability.

Experts also state that the quality of soft skills mastery can be seen from someone's behaviour including his or her interaction in the society, language proficiency, custom, or other behaviours which support someone's optimism [17]. Dewiyani [18] divides the soft skills into two categories: intrapersonal skill and interpersonal skill. Intrapersonal skills refer to 
an individual's ability in managing himself for optimally developing works, for example, time management, stress management and creative thinking. Meanwhile, interpersonal skills are defined as an individual's skills in managing their relationship with others for optimal work developments, i.e., an ability to motivate, to lead and to negotiate. For further explanation in this writing, these abilities will be referred to as attributes of soft skills.

In short, from the previous discussion, it can be concluded that the soft skills are everyone's ability which builds someone's character. The mastery of soft skills can be developed maximally and is one of the indicators needed in the work fields. The soft skills are the supplement to the hard skills. Both of them have to balance and support each other. So that, it is essential for the high school graduates to master the soft skills and it is a must for the teacher to develop the graduates' soft skills. Raman \& Koka [19] conducted a survey in 2015 to understand the importance and requirements of soft skills in the IT industry and also the causes behind the lack of soft skills in students. The study has revealed that problem solving skills (98\%), communication skills (92\%), interpersonal skills (88\%), time management skills (65\%) and team building skills (43\%) were among the top 5 skills which are sought after and these are followed by the other skills like emotional intelligence, motivation, positive attitude, presentation skills and decision-making skills.

The factor that makes someone survive in the work fields is $80 \%$ determined by his or her mindset and $20 \%$ determined by the technical skills. Lamancusa \& Simpson [20] elaborate their research finding that the work fields, both business fields and industrial fields, tend to employ the graduates whose have common sense, positive working ethos, and good communication ability. Moreover, the graduates can implement the basic principle to finish the work punctually, in a team, and based on the budget. Here are the graduates' skills needed in the business field or the industrial field. Table 1 presents the skill criteria in the business field or the industrial field.

Table 1. Skill Criteria in the Business Field or the Industrial Field

\begin{tabular}{ccc}
\hline No & Quality/Skill & Importance \\
\hline 1 & Communication Skills & 4,8 \\
2 & Honesty/Integrity & 4,7 \\
3 & Interpersonal Skills & 4,5 \\
4 & Motivation/Initiative & 4,5 \\
5 & Strong Work Ethic & 4,5 \\
6 & Teamwork Skills & 4,5 \\
7 & Analytical Skills & 4,4 \\
8 & Flexibility/Adaptability & 4,3 \\
9 & Computer Skills & 4,1 \\
10 & Detail Oriented & 4,0 \\
11 & Leadership Skills & 4,0 \\
12 & Organizational Skills & 4,0 \\
13 & Self-Confidence & 4,0 \\
14 & Friendly/Outgoing Personality & 3,8 \\
15 & Tactfulness & 3,8 \\
16 & Well Mannered/Polite & 3,8 \\
17 & Creativity & 3,6 \\
18 & GPA (3.0 or better) & 3,6 \\
19 & Entrepreneurial Skills & 3,2 \\
20 & Sense of Humour & 3,2 \\
\hline
\end{tabular}

Based on Table1, it can be seen that soft skills are needed by the graduates to achieve the success in the work field. As discussed before, the common problem faced by the work fields especially the industrial field is related to the soft skills aspect. Hence, the soft skills have the pivotal role for someone to start or do the work successfully and to avoid the risks in industrial world threat.

The research conducted by Setiani [21] showed that the teaching and learning process which could trigger the students' participation actively, attract the students' interest and attention, encourage the students' motivation, implement the autonomous learning principle and the learning media was effective media to improve the soft skills of vocational high school students. Based on previous research conducted, there is a difference of research with the researcher do, that this research is more focused on teacher component as an educator in equipping soft skills of graduates. The result of the study also indicated the teacher's role to train and guide the students to have good soft 
skills during the teaching and learning interaction. Conducting this study is important to identify how important the teacher's efforts in preparing the graduates' skills and to get information related to the teachers' obstacles to equip the graduates with soft skills.

\section{METHOD}

This study was descriptive quantitative research. The research population included vocational high schools in Yogyakarta, Indonesia which have the study program of building construction study program. The research samples were chosen by cluster sampling technique. There were 152 teachers from five vocational high schools in Yogyakarta as the respondents. The respondents were from SMKN 2 Depok, SMKN 3 Yogyakarta, SMKN 2 Wonosari, SMKN 1 Sedayu dan SMKN 2 Pengasih.

The data collection techniques used in this study were a questionnaire. The survey used a Likert-type scale questionnaire to identify the integration level of soft skills elements. The scales used in the questionnaire consisted of score 1, 2, 3, and 4 for the answers of wholly integrated, mostly integrated, less integrated and not integrated respectively.

Moreover, the teachers' obstacles in equipping the graduates' soft skills were categorized as scores $1,2,3$ and 4 for the answers of very sufficient, sufficient, less sufficient, and not sufficient respectively. The descriptive statistic data analysis steps included data scoring tabulating process and central tendency measuring. The data scoring was done at the Likert-scale questionnaire by giving the score of the respondents' responses. The tabulating process was done after giving the score of the respondents' responses. The results were shown by the frequency distribution table, bar chart, and histogram. Central tendency measuring was done to determine the central tendency which included mean, modus, median, and standard deviation using a software application named SPSS v.16. Then, it was set the criteria of categorization presented in Table 2 [22].

Table 2. The Criteria of Categorization

\begin{tabular}{lc} 
& Criteria \\
\hline$X \geq M+1.5 \mathrm{SD}$ & very high \\
$\mathrm{M}+0.5 \mathrm{SD} \geq \mathrm{X}<\mathrm{M}+1.5 \mathrm{SD}$ & high \\
$\mathrm{M}-0.5 \mathrm{SD} \geq \mathrm{X}<\mathrm{M}+0.5 \mathrm{SD}$ & sufficient \\
$\mathrm{M}-1.5 \mathrm{SD} \geq \mathrm{X}<\mathrm{M}-0.5 \mathrm{SD}$ & less sufficient \\
$\mathrm{X}<\mathrm{M}-1.5 \mathrm{SD}$ & low \\
\hline Where & \\
$\mathrm{X}:$ Modus & \\
$\mathrm{M}:$ Mean & \\
SD: standard deviation &
\end{tabular}

The explanation of each category was flexible based on the indicator or sub-variable which was categorized. Indeed, the formula of each category was the same.

\section{RESULTS AND DISCUSSION}

There were 50 question items to identify the integration level of soft skills elements. The highest and the lowest scores were 200 and 145 resepctively. The central tendency consisted of the mean (M) of 170.1513, the median (Me) of 166 , the modus (Mo) of 160 and the standard deviation (SD) of 15.68. After that, the integration level of soft skills data was categorized, and the criteria was made as shown in Table 3.

Table 3. Categorized Integration Element Soft Skills

\begin{tabular}{ccc}
\hline Number & Categorized & Interval \\
\hline 1 & Not sufficient & $\mathrm{x}<87.5$ \\
2 & Less sufficient & $87.5 \geq \mathrm{x}<112.5$ \\
3 & Sufficient & $112.5 \geq \mathrm{x}<137.5$ \\
4 & Good & $137.5>\mathrm{x}<162.5$ \\
5 & Very good & $\mathrm{x} \geq 162.5$ \\
\hline
\end{tabular}

As known that mean (M) score was 170.1513, based on Tabel 3, it can be concluded that the tendency of soft skills integration elements generally is categorized as very good. The integration level of soft skills elements was then categorized and presented in Table 4. It can be seen that all indicators of equipping the graduates' soft skills fulfil the criteria of wholly integrated. It means that each indicator was mostly integrated into the lesson 
by the teacher in order to prepare the graduates' soft skills. Indeed, it can be concluded that the results of the questionnaire are good.

\begin{tabular}{|c|c|c|}
\hline Num & $\begin{array}{l}\text { The Indicator of Equipping } \\
\text { the Graduates' Soft Skills }\end{array}$ & Criteria \\
\hline 1 & $\begin{array}{l}\text { Developing the } \\
\text { communication skill }\end{array}$ & $\begin{array}{l}\text { Wholly } \\
\text { integrated }\end{array}$ \\
\hline 2 & $\begin{array}{l}\text { Building the problem- } \\
\text { solving ability }\end{array}$ & Mostly integrated \\
\hline 3 & $\begin{array}{l}\text { Building the cooperative } \\
\text { ability }\end{array}$ & $\begin{array}{l}\text { Wholly } \\
\text { integrated }\end{array}$ \\
\hline 4 & Motivating ability & $\begin{array}{l}\text { Wholly } \\
\text { integrated }\end{array}$ \\
\hline 5 & $\begin{array}{l}\text { Developing the etiquette } \\
\text { and moral value }\end{array}$ & $\begin{array}{l}\text { Wholly } \\
\text { integrated }\end{array}$ \\
\hline 6 & $\begin{array}{l}\text { Developing the science } \\
\text { and technology mastery }\end{array}$ & Mostly integrated \\
\hline 7 & Building responsibility & $\begin{array}{l}\text { Wholly } \\
\text { integrated }\end{array}$ \\
\hline
\end{tabular}

There were 4 question items to identify the teachers' obstacles in equipping the graduates' soft skills. The highest and the lowest scores were 16 and 6 respectively. The calculation of central tendency showed the mean $(\mathrm{M})$ of 11.5987 , the median $(\mathrm{Me})$ of 12 , the modus (Mo) of 12 and the standard deviation (SD) of 2.288. Then the data categorization about the teachers' obstacles in equipping the graduates' soft skills was done as shown in Table 5.

Table 5. Categorized Soft Skills Integration Obstacles

\begin{tabular}{ccc}
\hline Number & Categorized & Interval \\
\hline 1 & Not impede & $\mathrm{x}<7$ \\
2 & Less impede & $7 \geq \mathrm{x}<8$ \\
3 & Quite impede & $8 \geq \mathrm{x}<11$ \\
4 & Impede & $11 \geq \mathrm{x}<13$ \\
5 & Very impede & $\mathrm{x} \geq 13$ \\
\hline
\end{tabular}

As previously discussed, the mean (M) score was 11.5987 , based on the table 3 it can be seen that the tendency of the teachers' obstacles in equipping the graduates' soft skills is categorized as 'impede'. Then, the categorization of teachers' obstacles in equipping the graduates' soft skills was done and is delivered in Table 6. Based on Table 6, it is known that the factors which impede the teachers in equipping the graduates' soft skills include the students' ignorance toward the soft skills value, the lack of students' parents and school stakeholder cooperation in developing the students' soft skills, the absence of soft skills training, and the unsupported school culture in building the students' soft skills. Those obstacles factors were categorized as 'impeded'.

Table 6. Teachers' Obstacles in Equipping the Graduates' Soft Skills

\begin{tabular}{|c|c|c|}
\hline Num & $\begin{array}{c}\text { The Indicator of } \\
\text { Equipping the Graduates' } \\
\text { Soft Skills }\end{array}$ & Criteria \\
\hline 1 & $\begin{array}{l}\text { The students' ignorance } \\
\text { attitude toward the value } \\
\text { of the soft skills }\end{array}$ & impeded \\
\hline 2 & $\begin{array}{l}\text { The lack of collaboration } \\
\text { between the students' } \\
\text { parents and the school } \\
\text { stakeholders in } \\
\text { developing the graduates' }\end{array}$ & impeded \\
\hline 3 & $\begin{array}{l}\text { soft skills } \\
\text { The absence of soft skills } \\
\text { training }\end{array}$ & impeded \\
\hline 4 & $\begin{array}{l}\text { The unsupported school } \\
\text { culture }\end{array}$ & impeded \\
\hline
\end{tabular}

This study is different from the preliminary study conducted by Kusumastuti, Ngadiman \& Sohidin [23] about the vocational high school efforts in qualifying the students' soft skills. The preliminary study stated that the vocational high school made some efforts to meet the work field and industrial field demand. The efforts included harmonizing the curriculum with the work and industrial field and holding character education in school. However, this study focused more on how the teachers are equipping the graduates' soft skills.

The teachers' efforts in equipping the students' soft skills became the main focus of this study because the teacher had the important role in the teaching and learning processes. Moreover, during the teaching and learning processes, the teacher was the one who transfers the knowledge, train and develops the students' character. The teacher's role also included developing the soft skills competencies. Besides, the identification of soft skills integration was made in more detailed for there were some indicators of soft skills as the 
basis. In this study, there were seven indicators to identify the soft skills integration. As a result, it could be known the level implementation of soft skills integration. The results of this study could give the recent picture of the teachers' efforts in equipping the students' soft skills. Moreover, it can be used by the teachers and the school stakeholder as the guideline to plan the school program which can improve the quality of graduates' soft skills.

There was a previous study conducted by Putra \& Kartowagiran [24] about the obstacles of soft skills integration. The results of the study stated that the factors which impeded the soft skills integration included the students' ignorance of soft skills, students' lack of motivation, the limited time to implement the soft skills, and the teachers' different perceptions in implementing soft skills. Based on that study, it could be concluded that the impeded factors came from two sources: the students' perception and the teachers' perception.

The impeded factors discussed in the preliminary study were different from the obstacles studied in this research. Therefore, in this research, the factors impeded the soft skills integration were seen from some perspectives included the students, the cooperation between the students' parents and the school, and the culture in the school. The preliminary study and this study had the similarity in discussing the obstacle from the students which were ignorance to soft skills.

\section{CONCLUSION}

Based on the data analysis and the discussion above, it can be concluded that the integration level of communicative ability was wholly integrated, the integration level of problem-solving ability was mostly integrated, the integration level of cooperative competence was wholly integrated, the integration level of motivating ability was wholly integrated, the integration level of developing etiquette and moral value was wholly integrated, the integration level of science and technology mastery was mostly integrated, and the integration level of building responsibility was wholly integrated. The teachers of building construction engineering obstacles in preparing the graduates' soft skills included the students' ignorance attitude of the soft skills value, the lack of collaboration between the students' parents and the school stakeholders in developing the graduates' soft skills, the absence of soft skills training and the unsupported school culture. Those obstacles impeded the graduates' soft skills.

\section{REFERENCES}

[1] F. Wastono, "Peningkatan Kemandirian Belajar Siswa SMK pada Mata Diklat Teknologi Mekanik dengan Metode Problem Based Learning," J. Pendidik. Teknol. dan Kejuru., vol. 22, no. 4, pp. 396-400, 2016.

[2] H. Byram and R. Wenrich, Vocational Education and Practical Arts in the Community School. New York: The Macmillan Company, 1956.

[3] R. N. Evans and L. H. Edwin, Foundation of Vocational Education. Ohio: Charles E. Merril Publishing Company, 1978.

[4] J. F. Thompson, Foundation of Vocational Education Social and Philosophical Concepts. New Jersey: Prentice-Hall, 1973.

[5] D. Suryanto, W. Kamdi, and S. Sutrisno, "Relevansi Soft Skills yang Dibutuhkan Dunia Usaha/Dunia Industri dengan yang Dibelajarkan di Sekolah Menengah Kejuruan," Teknol. dan Kejuru., vol. 36, no. 2, pp. 107-118, 2013.

[6] Kejuruan Direktorat Pembinaan Sekolah Menengah, "Rencana Strategis Direktorat Pembinaan SMK 20152019," Jakarta, 2015.

[7] P.H, Slamet, "Pengembangan SMK Model untuk Masa Depan," Cakrawala Pendidik., vol. 32, no. 1, pp. 14-26, 2013.

[8] F. Suleman, "Employability Skills of Higher Education Graduates: Little Consensus on a Much-discussed Subject," in 2nd International Conference on Higher Education 
Advances, 2016.

[9] M. Ariff Nazron, B. Lim, and J. L. H. Nga, "Soft Skills Attributes and Graduate Employability: A Case in Universiti Malaysia Sabah," Malaysian J. Bus. Econ., vol. 4, no. 2, pp. 65-76, 2017.

[10] B. Cimatti, "Definition, Development, Assessment of Soft Skills and Their Role for The Quality of Organizations and Enterprises," Int. J. Qual. Res., vol. 10, no. 1, pp. 97-130.

[11] N. Wibowo, "Upaya Memperkecil Kesenjangan Kompetensi Lulusan Sekolah Menengah Kejuruan dengan Tuntutan Dunia Industri," J. Pendidik. Teknol. dan Kejuru., vol. 23, no. 1, pp. 45-50, 2016.

[12] S. Ramlall and D. Ramlall, "The Value of Soft-Skills in the Accounting Profession: Perspectives of Current Accounting Students," Adv. Res., vol. 2, no. 11, pp. 645-654, 2014.

[13] E. Taylor, "Investigating the Perception of Stakeholders on Soft Skills Development of Students: Evidence from South Africa. Interdisciplinary," $J$. e-Skills Life Long Learn., vol. 12, pp. 18, 2016.

[14] R. H. Binsaeed, S. T. Unnisa, and L. J. Rizvi, "The Big Impact of Soft Skills in Today's Workplace," Int. J. Econ. Commer. Manag., vol. 5, no. 1, pp. 456463, 2017.

[15] H. T. T. Truong and R. S. Laura, "Essential Soft Skills for Successful Business Graduates in Vietnam," Sociol. Study, vol. 5, no. 10, pp. 759-763, 2015.

[16] C. Ernesto, O. Santos, V. Estrada Sentí, J. P. Febles Rodríguez, and C. O. Maldonado, "Importance of Soft Skills Training from an Early Age," Int. Res.
J. Eng. Technol., vol. 4, no. 5, pp. 1522, 2017.

[17] S. A. Hurrell, "Rethinking the Soft Skills Deficit Blame Game: Employers, Skills Withdrawal and the Reporting of Soft Skills Gaps," Hum. Relations, vol. 69, no. 3, pp. 605-628, 2016.

[18] M. J. Dewiyani, "Improving Students Soft Skills using Thinking Process Profile Based on Personality Types," Int. J. Eval. Res. Educ., vol. 4, no. 3, pp. 118-129, 2015.

[19] M. Raman and A. S. Koka, "The EverIncreasing Demand for Soft Skills at Workplace: A Study on IT Professionals' Perspectives," Int. Conf. Manag. Inf. Syst., vol. 18, no. 20, pp. 48, 2015.

[20] J. S. Lamancusa, P. State, and L. Bldg, "The Learning Factory-10 Years of Impact at Penn State," in International Conference on Engineering Education, pp. 1-8.

[21] F. Setiani and R. Rasto, "Mengembangkan Soft Skill Siswa Melalui Proses Pembelajaran," $J$. Pendidik. Manaj. Perkantoran, vol. 1, no. 1, pp. 170-176, 2016.

[22] A. Sudijono, Pengantar Evaluasi Pendidikan. Jakarta: PT Grafindo Persada, 2013.

[23] R. Kusumastuti, Ngadiman, and Sohidin, "Upaya SMK Bidang Studi Bisnis Manajemen dalam Memenuhi Kebutuhan Soft Skill Dunia Industri," Jupe-Jurnal Pendidik. Ekon., vol. 1, no. 3, pp. 1-13, 2013.

[24] Y. M. Putra and B. Kartowagiran, "Strategi Integrasi Soft Skills dalam Pembelajaran Praktik Pengelasan," $J$. Din. Vokasional Tek. Mesin, vol. 2, no. 2, p. 89, 2017. 